\title{
Investigation of mycobacteria in Crohn's disease tissue by Southern blotting and DNA hybridisation with cloned mycobacterial genomic DNA probes from a Crohn's disease isolated mycobacteria
}

\author{
P D BUTCHER, J J McFADDEN, AND J HERMON-TAYLOR \\ From the Department of Surgery, St George's Hospital Medical School, London
}

SUmmary A mycobacterial aetiology for Crohn's disease (CD) has been suggested. Slow growing mycobacteria indistinguishable from $M$ paratuberculosis, the causative agent of enteritis in ruminants (Johne's disease) have been isolated from CD tissues. We have used cloned genomic DNA probes derived from a CD isolated mycobacteria strain Ben, to investigate the presence of mycobacterial DNA sequences in CD tissues. DNA was extracted from total tissue from 17 CD and four control gut specimens. DNA was digested with restriction endonucleases, electrophoresed and transferred to nylon membranes by Southern blotting and hybridised to radiolabelled DNA probes. No mycobacterial DNA was detected in any tissue sample studied. Reconstitution experiments with known numbers of in vitro cultured mycobacteria showed sensitive detection of mycobacterial DNA. DNA extracted from mouse liver, infected with $M$ lepraemurium revealed a strong hybridisation signal and showed the applicability of the experimental approach to the detection of mycobacterial DNA in naturally infected tissues. The results do not provide evidence for the involvement of mycobacteria in the pathogenesis of $\mathrm{CD}$ but do not exclude the possibility of low levels of infection in subsets of intestinal cells with spheroplast or cell wall deficient forms of mycobacteria.

An infectious aetiology for Crohn's disease (CD) has often been suggested. ${ }^{1-5}$ Macroscopic and histological similarities between $\mathrm{CD}$, intestinal tuberculosis in man and paratuberculosis in ruminants (Johne's disease) caused by Mycobacterium paratuberculosis ${ }^{67}$ have led to the suggestion that mycobacteria may also be involved in $\mathrm{CD},{ }^{89}$ even though earlier studies failed to show the presence of acid fast mycobacteria. ${ }^{10} 11$ Burnham et al ${ }^{12}$ have isolated, after prolonged culture, a mycobacterium similar to $M$ kansasii from a lymph node of one out of 27 cases of $\mathrm{CD}$, as well as unidentified pleomorphic, cell wall deficient organisms (spheroplasts) from 22 of these $\mathrm{CD}$ cases, and one of 11 non-inflammatory disease controls. They suggested that mycobacterial spheroplasts might be an aetiological agent in $\mathrm{CD}$. Sphero-

Address for correspondence: Dr P D Butcher, Department of Gastroenterology, St Bartholomew's Hospital, West Smithfield, London EC1A 7BE. Received for publication 15 April 1988. plast forms of common bacteria have been found in various inflammatory diseases of the intestine..$^{13}$

A slow growing, mycobactin (an iron chelating growth factor) dependent Mycobacterium species has recently been isolated from three of $14 \mathrm{CD}$ gut tissues, but not controls, after 18 months culture. ${ }^{14}$ This organism was similar to M paratuberculosis and oral inoculation of neonatal goats with these isolates produced granulomatous, non-caseating tuberculoid ileitis within three to five months ${ }^{15}$ from which mycobacteria were reisolated. ${ }^{16}$ Subsequently, a further similar isolate has been recovered from CD tissue. ${ }^{17}$ These $\mathrm{CD}$ mycobacterial isolates were initially recovered in primary culture as slow growing spheroplasts which reverted to bacillary form only after prolonged and repeated subculture. The spheroplast ancestry of the CD bacillary isolates was confirmed by the analysis of restriction fragment length polymorphisms of ribosomal genes by DNA hybridisation. ${ }^{18}$ We have also shown that these $\mathrm{CD}$ 
isolated mycobacteria are identical to each other and to $M$ paratuberculosis by the use of DNA probes which identify restriction fragment length polymorphisms. ${ }^{1920}$ Unidentified spheroplasts were recovered from $61 \%$ of $\mathrm{CD}$ tissues but not controls. ${ }^{17}$ Several other groups have recently reported independently the isolation of mycobacteria from $\mathrm{CD}$ tissues of types similar to $M$ paratuberculosis as well as to $M$ chelonei and $M$ avium. ${ }^{22} 23$

The repeated isolation from $C D$ tissues of a mycobacterial pathogen may be of aetiological significance in $\mathrm{CD}$. The fastidious growth requirements, however, and long term cultures of CD derived organisms, makes their study protracted and very difficult. Their possible presence as spheroplasts or cell wall deficient forms also precludes their detection in CD tissue by microscopy. Direct demonstration of mycobacterial forms in CD tissues must therefore rely on alternative techniques. Detection of mycobacterial genomes by DNA hybridisation would provide a rapid and sensitive approach to this problem. A recent report of DNA-DNA hybridisation in solution of CD tissue total DNA with total DNA from a CD mycobacterial isolate demonstrated mycobacterial DNA sequences in both CD and control gut tissue. ${ }^{24}$

Precise identification of mycobacteria in CD tissue is necessary, however, for their aetiological significance to be evaluated, particularly if closely related non-pathogenic species such as $M$ avium may be found in control tissue. We have therefore used a more specific method to detect DNA sequences of mycobacterial origin that makes use of cloned genomic DNA probes derived from a CD mycobacterial isolate, strain Ben identified as $M$ paratuberculosis. ${ }^{1420}$ These probes are Mycobacterium specific and have been used to differentiate between mycobacterial species by restriction fragment length polymorphism analysis. ${ }^{2021} \mathrm{We}$ report here the use of cloned DNA probes to attempt to detect mycobacterial DNA in tissue derived DNA from 17 CD and four control gut tissues by Southern blotting after restriction endonuclease digestion of test DNA and hybridisation with radiolabelled probes.

\section{Methods}

TISSUE SOURCE

Specimens of colon and terminal ileum were removed under sterile conditions from Crohn's disease patients undergoing surgical resection at $\mathrm{St}$ George's Hospital between September 1983 and June 1986. Full thickness intestinal specimens were taken from involved areas showing typical thickening, cobblestoning and ulceration. All cases of CD were confirmed by clinical, radiological, and histo- logical criteria. Disease control tissues were from cases of colon carcinoma. Specimens were trimmed of fat, washed in sterile saline and snap frozen in liquid nitrogen and stored at $-70^{\circ} \mathrm{C}$. The total number of intestinal specimens screened for all forms of mycobacteria in this report were $17 \mathrm{CD}$ (two colon, one jejunum, 14 terminal ileum) and four controls (one colon, three terminal ileum).

DNA EXTRACTION

DNA was extracted from tissue homogenates by an enzymic procedure ${ }^{25}$ shown to extract DNA from bacillary mycobacteria which are resistant to lysis by conventional DNA extraction procedures. Briefly, tissue in TEN buffer $(50 \mathrm{mM}$ Tris- $\mathrm{HCl}, \mathrm{pH} 8,150 \mathrm{mM}$ $\mathrm{NaCl}, 100 \mathrm{mM}$ EDTA) was sequentially digested with $10 \mathrm{mg} / \mathrm{ml}$ Subtilisin (Sigma; protease Type VIII) at $37^{\circ} \mathrm{C}$ for three hours, $50 \mathrm{mg} / \mathrm{ml}$ lysozyme at $50^{\circ} \mathrm{C}$ for three hours and $3 \mathrm{mg} / \mathrm{ml}$ pronase (Calbiochem) at $37^{\circ} \mathrm{C}$ for 12 hours after the addition of $1 \%$ SDS. DNA recovered by phenol/chloroform extraction and ethanol precipitation was redissolved in TE $(10 \mathrm{mM}$ Tris- $\mathrm{HCl}, \mathrm{pH} 8,1 \mathrm{mM}$ EDTA) and treated with 10 $\mu \mathrm{g} / \mathrm{ml}$ RNA'ase A for two hours at $37^{\circ} \mathrm{C}$ after heating to $65^{\circ} \mathrm{C}$ for 15 minutes. DNA was again phenol/ chloroform extracted, ethanol precipitated from 0.1 $\mathrm{M} \mathrm{NaCl}$ and redissolved in TE buffer. DNA concentration was measured by absorbance at $260 \mathrm{~nm}$ ( $1 \mathrm{~A}_{260}$ unit $=50 \mu \mathrm{g} / \mathrm{ml}$ ) and its integrity checked by agarose gel electrophoresis. High molecular weight DNA was obtained in all cases.

\section{PROBES}

Cloned mycobacteria specific probes used in this study were from the $\mathrm{CD}$ derived $M$ paratuberculosis isolate, strain Ben ${ }^{14}$. BamH1 fragments of genomic DNA were cloned into the plasmid vector pGEM-1 as previously described. ${ }^{20}$ Probes were selected for their ability to detect and discriminate between a range of mycobacteria on the basis of restriction fragment length polymorphisms (RFLP). Three clones were used: (i) pMB22; with a $5 \mathrm{~kb}$ insert including a $1.2 \mathrm{~kb}$ repetitive element within it that is repeated greater than 10 times in $M$ paratuberculosis; (ii) pMB21; this clone hybridises equally well to $M$ paratuberculosis, $M$ avium, $C D$ isolates, and less to $M$ kansasii; (iii) pMB19; this clone hybridises equally well to $M$ paratuberculosis, CD isolates, $M$ avium, and $M$ kansasii The clone pMB19 has also been shown to hybridise to $M$ bovis, $M$ tuberculosis, $M$ intracellulare, and $M$ chelonei. These clones and the RFLP's they generate have been described in detail previously. .0-21 $^{20}$

Radiolabelled DNA probes were prepared for hybridisation by BamH1 excision of the cloned insert and separation by electrophoresis in low temperature 


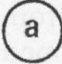

(b)

\section{$12345 \quad 67 \quad 8 \quad 91011121314$}

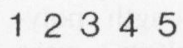

67

891011121314
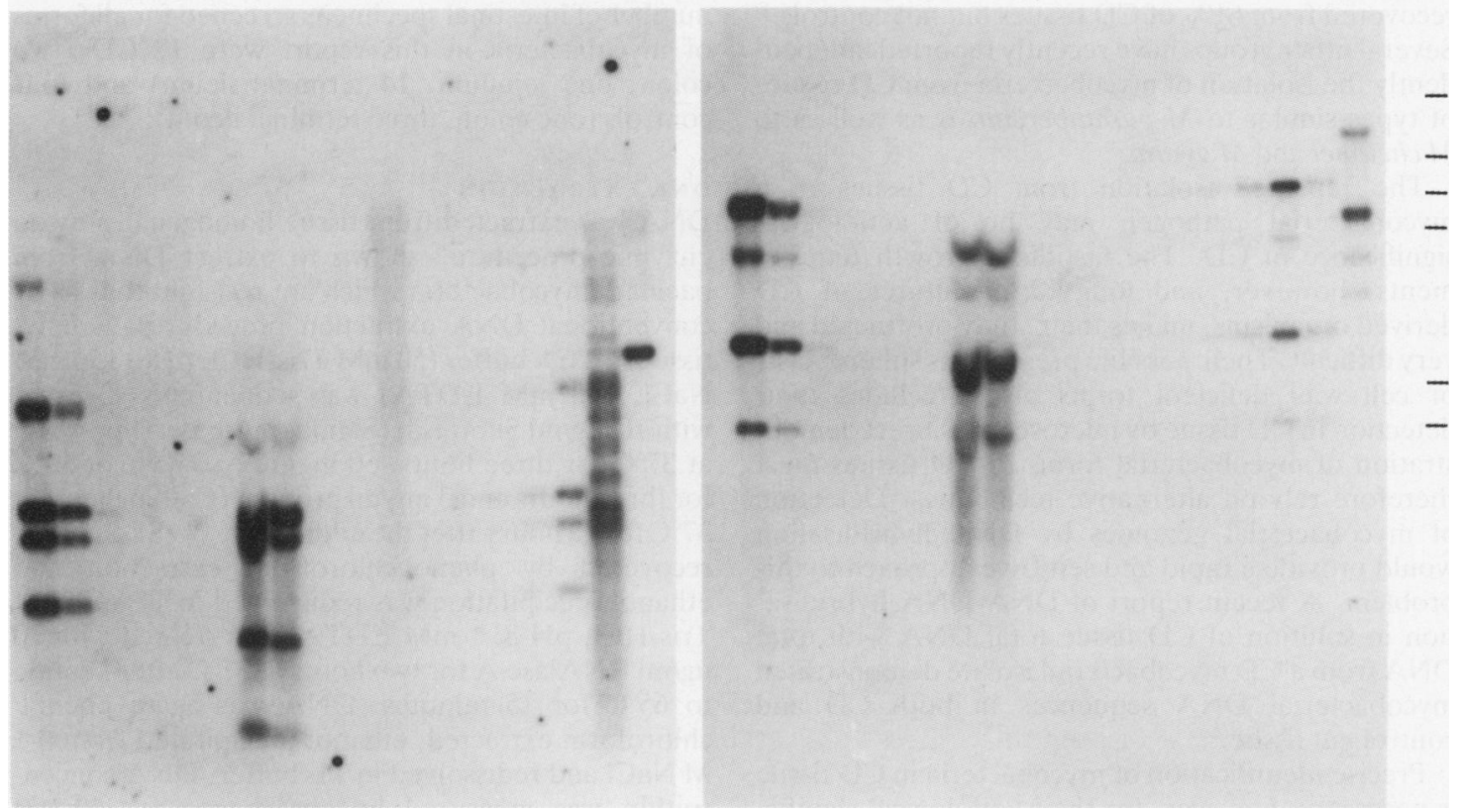

Fig. 1 Specificity and sensitivity of detection of mycobacterial DNA sequences using cloned genomic DNA probes. Lanes 1-5 (respectively): total DNA, $1 \mu \mathrm{g}$, from normal human gut tissue reconstituted with known numbers of $\mathrm{M}$ avium bacilli: $5 \times 10^{6}, 2 \times 10^{\natural}, 2 \times 10^{5}, 5 \times 10^{4}, 1 \times 10^{4}$. Lanes 6 and 7: $10 \mu \mathrm{g}$ DNA from mouse liver infected with $\mathrm{M}$ lepraemurium. Lane 8: $10 \mu \mathrm{g}$ normal human leucocyte DNA. Lanes $9-12$ (respectively): $1,5,20$, and $50 \mathrm{ng}$ DNA from $\mathrm{M}$ avium bacilli. Lanes 13 and 14: $10 \mathrm{ng}$ of DNA from $\mathrm{M}$ paratuberculosis and $200 \mathrm{ng}$ of DNA from $\mathrm{M}$ phlei, respectively. DNA was electrophoresed after $P V U-11$ restriction endonuclease digestion, Southern blotted and hybridised consecutively with the following probes: (a) pMB22 and (b) pMB21 and autoradiographed. Molecular weight size markers are indicated (-) and are from the top of the gel $21,9 \cdot 4,6 \cdot 6,4 \cdot 4,2 \cdot 3$, and $2 \cdot 0$ kilobase pairs $(\mathrm{kb})$.

gelling agarose; $20-25 \mathrm{ng}$ were radiolabelled with 50 uCi [ $\left.{ }^{32} \mathrm{P}\right]$ deoxy CTP (Amersham; $3000 \mathrm{Ci} / \mathrm{mmol}$ ) by hexanucleotide random priming and Klenow extension. ${ }^{26}$ Double stranded DNA probe was denatured by boiling before hybridisation. Specific activities of $4 \cdot 1-9 \cdot 8 \times 10^{*} \mathrm{cpm} / \mu \mathrm{g}$ DNA were obtained with approximately $80 \%$ incorporation of the label.

\section{HYBRIDISATION}

Extracted DNA was digested with restriction endonuclease Hinf1 and PVU-11 and $10 \mu \mathrm{g}$ electrophoresed on $1 \%$ agarose gels, denatured in $0.4 \mathrm{M}$ $\mathrm{NaOH}$, neutralised and transferred by Southern blotting to nylon filters (Amersham; Hybond-N) following standard protocols. ${ }^{27}$ DNA was crosslinked to the filters by ultraviolet irradiation and the filters prehybridised for 18 hours at $65^{\circ} \mathrm{C}$ in hybridisa- tion solution: $3 \times \mathrm{SSC}(1 \times \mathrm{SSC}=0 \cdot 15 \mathrm{M} \mathrm{NaCl}, 0 \cdot 015$ $\mathrm{M}$ Na citrate, $\mathrm{pH} 7 \cdot 0$ ), $10 \mathrm{mM} \mathrm{NaH}_{2} \mathrm{PO}_{4}, \mathrm{pH} 7,0.5 \%$ SDS, $0.05 \%$ BSA, $0.05 \%$ polyvinyl pyrrolidine, $0.05 \%$ Ficol, $10 \%$ dextran sulphate and $110 \mu \mathrm{g} / \mathrm{ml}$ denatured salmon sperm DNA. Hybridisation was continued by the addition of the boiled radiolabelled probe for 18 hours at $65^{\circ} \mathrm{C}$. Filters were then removed and washed at $65^{\circ} \mathrm{C}$ in $3 \times \mathrm{SSC}, 0 \cdot 1 \%$ SDS for $3 \times 15$ minutes and then $2 \times 30$ minutes in $1 \times \mathrm{SSC}, 0 \cdot 1 \%$ SDS. Hybridisation of the labelled probe with target DNA was detected by autoradiography at $-70^{\circ} \mathrm{C}$ with intensifying screens for up to 30 days. Filters were reprobed with a fresh probe after removal of previous probe with $0.4 \mathrm{M} \mathrm{NaOH}$ at $45^{\circ} \mathrm{C}$ for 45 minutes followed by neutralisation in $0.2 \mathrm{M}$ Tris$\mathrm{HCl}, \mathrm{pH} \mathrm{7.4,1 \times SSC}$. In this way filters can be reprobed repeatedly without loss of signal. 


\section{Results}

SENSITIVITY AND APPLICABILITY OF THE

EXPERIMENTAL APPROACH

In order to quantify the sensitivity of this approach to the detection of mycobacteria in CD tissue, a reconstitution experiment was done in which dilutions of freshly cultured $M$ avium ranging from $10^{9}$ to $10^{5}$ bacilli were added to $0.1 \mathrm{ml}$ of total control gut tissue homogenate (equivalent to $0.03 \mathrm{~g}$ of tissue). M avium DNA was detected after coextraction with tissue DNA by hybridisation with the DNA probes. Approximately $50 \mu \mathrm{g}$ DNA was recovered from each extraction, and $1 \mu \mathrm{g}$ was loaded in each lane for electrophoresis. The results are shown in Figure 1. The minimal detectable signal was obtained with $2 \times 10^{5}$ bacilli (lane 3, Fig. 1a and b). A separate experiment in which known amounts of pure $M$ avium DNA, digested with PVU-11, were electrophoresed and hybridised with probes pMB21 and
Table 1 Limits of detection of Mycobacterial DNA using the three cloned genomic DNA probes: expressed as one mycobacterial genome per number of human cells

\begin{tabular}{llll}
\hline & Probe & & \\
\cline { 2 - 4 } Mycobacterial species & $p M B 22$ & $p M B 21$ & $p M B 19$ \\
\hline M paratuberculosis & $1 / 100$ & $1 / 10$ & $1 / 10$ \\
Mavium-intracellulare & $1 / 10$ & $1 / 10$ & $1 / 10$ \\
M kansasii & $1 / 5$ & $1 / 5$ & $1 / 10$ \\
\hline
\end{tabular}

pMB22 showed that the minimal detectable amount of DNA was $1 \mathrm{ng}$ after autoradiography; see (Fig. 1a and $b$ lanes 9-12). The signal obtained from $1 \mathrm{ng}$ mycobacterial DNA was routinely visible against the negligible hybridisation background of $10 \mu \mathrm{g}$ human DNA as may be observed in Fig. 1b, lane 8 and Fig. 3 . Based on genome sizes of $3.1 \times 10^{9}$ daltons for $M$ avium $^{28}$ and $3 \times 10^{12}$ daltons for humans, this was

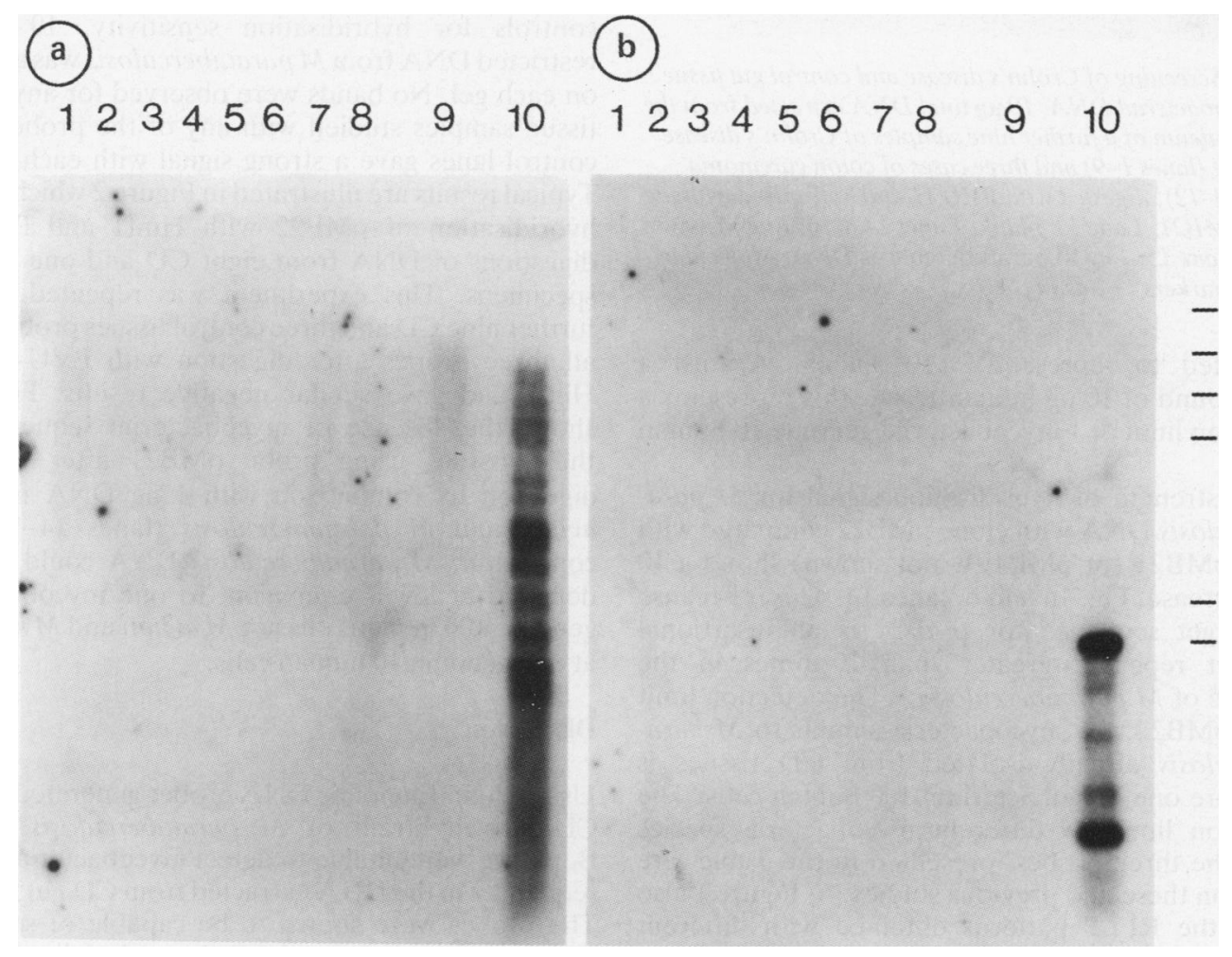

Fig. 2 Screening of Crohn's disease and control gut tissue for mycobacterial DNA. $10 \mu \mathrm{g}$ total DNA from terminal ileum of eight cases of Crohn's disease (lanes 1-8) and 1 control (lane 9), digested with PVU-11 (a) or with Hinfl (b) restriction endonuclease and hybridised with probe pMB22. Lane 10:10 ng M paratuberculosis DNA. Molecular weight markers (-) as in Fig. 1. 


\section{6}

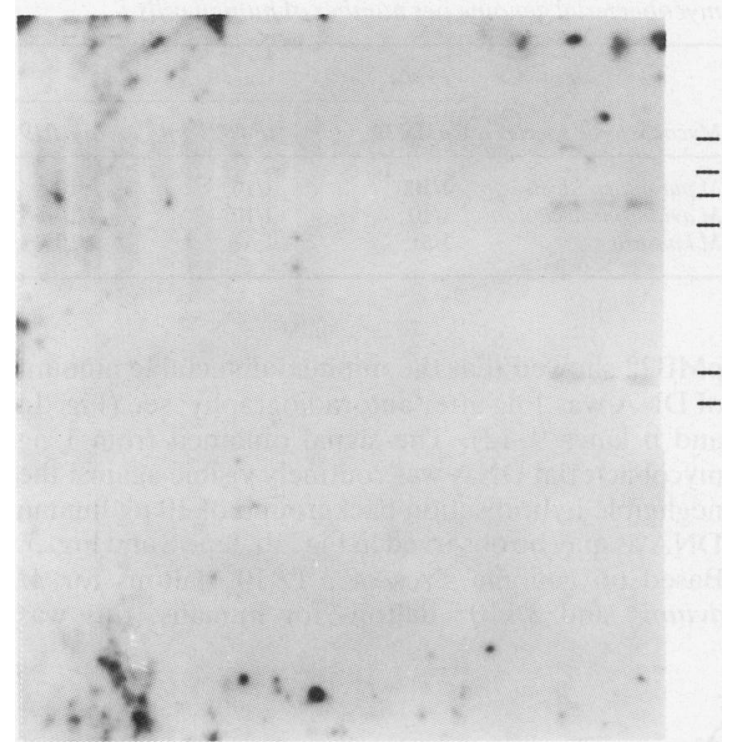

Fig. 3 Screening of Crohn's disease and control gut tissue for mycobacterial DNA. $10 \mu \mathrm{g}$ total DNA extracted from the terminal ileum of a further nine samples of Crohn's disease gut tissue (lanes 1-9) and three cases of colon carcinoma (lanes 10-12), digested with PVU 11 and hybridised with the probe pMB21. Lane 13: blank. Lanes 14 \& 16: 1 ng M avium DNA. Lane 15: 1 ng M paratuberculosis DNA. Molecular weight markers (-) as Fig. 1.

calculated to represent $2 \times 10^{5}$ bacilli. Against a background of $10 \mu \mathrm{g}$ human DNA, this represents a detection limit of 1 mycobacterial genome/10 human cells.

The strength of hybridisation signal for $M$ paratuberculosis DNA with clone pMB22 compared with clone pMB21 (or pMB19 - not shown) shows a 10 fold increase, Fig. 1a and b, lanes 13. This is because the target sequence for pMB22 is an insertional element repeated greater than 10 times in the genome of $M$ paratuberculosis. ${ }^{20}$ The detection limit using pMB22, for mycobacteria similar to $M$ paratuberculosis already isolated from $\mathrm{CD}$ tissues is therefore one Mycobacterium/100 human cells. The detection limit for different mycobacteria species using the three probes, presented in the Table, are based on these and previous studies. ${ }^{2121}$ Figure 1 also shows the RFLP patterns obtained with different species and shows that $M$ avium, $M$ paratuberculosis, and $M$ phle $i$ are clearly and precisely distinguishable.

To show the applicability of this experimental approach to detecting naturally occurring mycobacterial infections we applied these techniques to $40 \mathrm{mg}$ liver from a mouse infected with $M$ lepraemurium. Hybridisation analysis with clones pMB22 and pMB21 showed a very strong signal after autoradiography, Fig. 1a and b, lanes 6 and 7. The signal obtained was at least as strong as that from $5 \times 10^{6} M$ avium bacilli, which against a background of $10 \mu \mathrm{g}$ mouse DNA represents an infection level of approximately 2.5 organisms/mouse liver cell. Clearly from Figure 1, lanes 1-3, at least a 25 -fold reduction in signal would still be detectable, indicating a level of sensitivity of detection for $M$ lepraemurium of one organism/ 10 cells.

DETECTION OF MYCOBACTERIAL DNA WITHIN CD INTESTINAL DNA EXTRACTS

DNA was extracted from full thickness involved intestinal specimens from a total of 17 cases of $C D$ and four normal control colon carcinoma cases. A maximum of $10 \mu \mathrm{g}$ restriction endonuclease digested DNA (equivalent to DNA from approximately $6 \mathrm{mg}$ of tissue) was electrophoresed in each lane, blotted onto nylon filters and hybridised consecutively with the three cloned probes, as described. As internal controls for hybridisation sensitivity, $10 \mathrm{ng}$ of restricted DNA from $M$ paratuberculosis was also run on each gel. No bands were observed for any of the tissue samples studied with any of the probes. The control lanes gave a strong signal with each probe. Typical results are illustrated in Figure 2 which shows hybridisation of pMB22 with Hinf1 and PVU-11 digestions of DNA from eight $\mathrm{CD}$ and one control specimens. This experiment was repeated with a further nine $C D$ and three control tissues probed with all three probes after digestion with PVU-11 and Hinf1 and gave similar negative results. Figure 3 shows the absence of mycobacterial sequences in these tissues using probe pMB21 after PVU-11 digestion by comparison with $1 \mathrm{ng}$ DNA from $M$ avium and $M$ paratuberculosis (lanes 14-16). In conclusion, $M$ paratuberculosis DNA could not be detected at levels equivalent to one mycobacterial genome/100 human cells nor $M$ avium and $M$ kansasii at one genome/10 human cells.

\section{Discussion}

Using cloned genomic DNA probes generated from a CD-derived strain of $M$ paratuberculosis, strain $B^{14}{ }^{14}$, we were unable to detect mycobacterial DNA sequences in the DNA extracted from CD gut tissues. The probes were shown to be capable of sensitive detection of mycobacterial DNA and of discriminating between closely related mycobacteria by restriction fragment length polymorphism analysis ${ }^{2012}$ (RFLP). The combination of the three probes used in this study would have detected DNA related to $M$ paratuberculosis, $M$ avium-intracellulare, and $M$ 
kansasii, all species that have been variously isolated from $C D$ tissues. The maximum levels of sensitivity achieved for the detection of $M$ paratuberculosis was one organism/100 human cells and for the other species one organism/10 cells. Whether such levels might be similar to natural infections by these organisms is unknown. Certainly acid fast bacilli at these levels have not been detected by staining. ${ }^{11}$ Cell wall deficient or spheroplast forms of mycobacteria which have been recovered from cultures of Crohn's disease tissue by several groups ${ }^{1214223}$ may be the natural intracellular form of mycobacteria in $\mathrm{CD}$, as previously suggested. ${ }^{12}$ There are, however, no data available for the intracellular abundance of these forms of mycobacteria. We suggest that if these forms do occur in $C D$ then they persist at levels beyond our present methods of detection in subsets of cells permissive to invasion by and persistence of mycobacteria, such as macrophages or giant cells within granulomata.

Although extraction methods and sensitivity calculations were based on in vitro cultured $M$ avium bacilli, $M$ lepraemurium infected mouse liver provided a positive control for the application of our methods to the detection of intracellular forms of mycobacteria. Our DNA extraction method has also been successfully applied to an in vitro cultured spheroplast like organism recovered from $C D$ tissue. ${ }^{29}$ We therefore believe that spheroplasts, if present in CD tissue, would have been susceptible to the extraction methods used. Nevertheless, the absence of mycobacterial DNA at these levels of sensitivities does not exclude a mycobacterial aetiology for $\mathrm{CD}$ because some mycobacterial infections (lepromatous leprosy in man or $M$ paratuberculosis infections in ruminants) produce large numbers of bacilli, while others are associated with very few undetectable organisms in tissues (tuberculosis and tuberculous leprosy). In this regard it is relevant to report that attempts by us to detect $M$ tuberculosis DNA in several human tuberculous cervical lymph nodes were unsuccessful (unpublished observations).

A recent report has shown the presence of mycobacterial DNA in CD and control tissue derived DNA using solution hybridisation with $C D$ isolated mycobacteria strain Linda total DNA as probe. ${ }^{24}$ The thermal stability data for their DNA hybrids indicated that these sequences were neither identical to each other nor to strain Linda and they concluded that one mycobacterial species may not be specifically associated with $\mathrm{CD}$. The levels of mycobacteria they found ranged between one organism/two human cells to one/700 cells. The total absence of mycobacterial DNA sequences observed in our present study may reflect our slightly lower sensitivity range or the specificity of cloned probes which readily distinguish a positive banding pattern from background hybridisation. A previous study by us also failed to show mycobacterial DNA in mesenteric lymph nodes from 21 cases of $C D{ }^{30}$

Clearly even more sensitive techniques than those described here providing precise information on the organisms detected are required. Gene amplification techniques using the polymerase chain reaction have recently been described that may enrich a specific DNA sequence more than a million fold..$^{32}$ With the DNA sequence data for specific mycobacterial target DNA at present being obtained in this laboratory, these methods combined with Southern blotting and RFLP analysis should provide crucial information concerning the possible mycobacterial aetiology of Crohn's disease.

This work was supported by grants from Action Research for The Crippled Child and The Anthony and Elizabeth Mellows Charitable Trust to whom we would like to express our sincere thanks.

\section{References}

1 Mayberry JF, Rhodes J. Epidemiological aspects of Crohn's disease: a review of the literature. Gut 1984; 25: 886-99.

2 Allan A. Inflammatory bowel disease: Aetiology and epidemiology. Curr Opin Gastroenterol 1985; 1: 461-7.

3 Mitchell DN, Rees RJW. Possible role of infectious agents in Crohn's disease. Z Gastroenterol 1979; 17: 98100.

4 Beeken WL. Transmissible agents in inflammatory bowel disease. Med Clin N Am 1980; 64: 1021-35.

5 Pena AS, Weterman IT, Booth CC, Strober W, eds. Recent advances in Crohn's disease. Developments in Gastroenterology 1. London: Martinus-Nijhoff, 1981.

6 Patterson DSP, Allan WM. Chronic mycobacterial enteritis in ruminants as a model of Crohn's disease. Proc R Soc Med 1972; 65: 998-1001.

7 Chiodini RJ, van Kruiningen HJ, Merkal RS. Ruminant paratuberculosis (Johne's disease): the current status and future prospects. Cornell Vet 1984; 74: 218-62.

8 Golde DW. Aetiology of regional enteritis. Lancet 1968; i: 1144-5.

9 Gitnick G. Is Crohn's disease a mycobacterial disease after all? Dig Dis Sci 1984; 29: 1086-8.

10 Wilensky A, Moschcowitz E. Non specific granuloma of the small intestine. Am J Med Sci 1927; 173: 374-80.

11 Crohn BB, Ginsberg L, Oppenheimer GD. Regional ileitis. A pathological and clinical entity. JAMA 1932; 99: 1323-9.

12 Burnham WR, Lennard-Jones JE, Stanford JL, Bird RG. Mycobacteria as a possible cause of inflammatory bowel disease. Lancet 1978; ii: 693-6.

13 Belsheim MR, Darwish RZ, Watson WC, Schieven B. Bacterial form isolation from inflammatory bowel disease patients. Gastroenterology 1983; 85; 364-9.

14 Chiodini RJ, van Kruiningen HJ, Thayer WR, Merkal RS, Coutu JA. Possible role of mycobacteria in inflammatory bowel disease. 1 An unclassified mycobacterium 
species isolated from patients with Crohn's disease. Dig Dis Sci 1984; 29: 1073-9.

15 Chiodini RJ, van Kruiningen HJ, Merkel RS, Thayer WR, Coutu JA. Characteristics of an unclassified mycobacterium species isolated from patients with Crohn's disease. J Clin Microbiol 1984; 20: 966-71.

16 van Kruiningen HJ, Chiodini RJ, Thayer WR, Coutu JA, Merkal RS, Runnels PL. Experimental disease in infant goats induced by a mycobacterium isolated from a patient with Crohn's disease. Dig Dis Sci 1986; 31: 135160.

17 Chiodini RJ, van Kruiningen HJ, Thayer WR, Couteau JA. Spheroplastic phase of mycobacteria from Crohn's disease. J Clin Microbiol 1986; 24: 357-63.

18 Chiodini RJ, van Kruiningen HJ, Thayer WR, Coutu JA. Differentiation of the mycobacterium $\mathrm{sp}$. from Crohn's disease by restriction fragment length polymorphism of the ribosonal genes [Abstract]. Gastroenterology 1986; 90: 1372.

19 McFadden JJ, Butcher PD, Chiodini RJ, HermonTaylor J. Determination of genome size and DNA homology between an unclassified mycobacterium species isolated from patients with Crohn's disease and other mycobacteria. J Gen Microbiol 1987; 133: 211-4.

20 McFadden JJ, Butcher PD, Chiodini RJ, HermonTaylor J. Crohn's disease-isolated mycobacteria are identical to Mycobacterium paratuberculosis, as determined by DNA probes that distinguish between Mycobacterial species. J Clin Microbiol 1987; 25: 796-801.

21 McFadden JJ, Butcher PD, Thompson J, Chiodini R, Hermon-Taylor $\mathbf{J}$. The use of DNA probes identifying restriction fragment length polymorphisms to examine the Mycobacterium avium complex. Mol Microbiol 1987; 1: 283-91.

22 Graham DY, Markesich DC, Yoshimura HH. Mycobacteria and inflammatory bowel disease. Results of culture. Gastroenterology 1987; 92: 436-42.
23 Collins JB, Beaman B, Arthur M. Gitnick G. Isolation of mycobacteria from intestinal tissues [Abstract]. Gastroenterology 1986; 90: 177.

24 Yoshimura HH, Graham DY, Estes MK, Merkal RS. Investigation of association of mycobacteria with inflammatory bowel disease by nucleic acid hybridisation. J Clin Microbiol 1987; 25: 45-51.

25 Patel R, Kuach JT, Mounts P. Isolation and restriction endonuclease analysis of Mycobacterial DNA. J Gen Microbiol 1986; 132: 541-51.

26 Feinberg AP, Vogelstein B. A technique for radiolabelling DNA restriction fragments to high specific activity. Anal Biochem 1984; 137: 226-7.

27 Maniatis T, Fritsch EF, Sambrook J. Molecular cloning - A laboratory manual. New York: Cold Spring Harbor Laboratory Publications, 1982.

28 Baess I. Determination and re-examination of genome sizes and base ratios on deoxyribonucleic acid from Mycobacteria. Acta Pathol Microbiol Immunol Scand 1984; B92: 209-11.

29 McFadden JJ, Thompson J, Hull E, Hampson S, Stanford J, Hermon-Taylor J. The use of cloned DNA probes to examine organisms isolated from Crohn's disease tissue. 1987 In: MacDermott, ed. Inflammatory bowel disease: current status and future approach. Amsterdam: Elsevier, 1988.

30 Butcher PD, McFadden JJ, Hermon-Taylor J. The use of cloned mycobacterial DNA probes for the detection of Mycobacteria in Crohn's disease tissue. Biochem Soc Trans 1987; 15: 547-9.

31 Saike RK, Scharf S, Faloona F, et al. Enzymatic amplification of beta globin genomic sequences and restriction site analysis for diagnosis of sickle cell disease. Science 1985; 230: 1350-4.

32 Saike RK, Gelfand DH, Stoffel S, et al. Primer-directed enzymatic amplification of DNA with a thermostable DNA polymerase. Science 1988; 239: 487-91. 